\title{
Effect of Molybdenum Content on Creep-rupture Strength and Toughness of $9 \%$ Chromium Ferritic Heat Resisting Steels Containing $\mathrm{V}$ and $\mathrm{Nb}$
}

\section{Kentaro Asakura, Toshio Fujita and Hisashi Watanabe}

\begin{abstract}
Synopsis:
The effect of molybdenum content on creep-rupture properties and room-temperature toughness of high chromium ferritic heat resisting steels was investigated. Molybdenum content was varied from 1 to $2 \mathrm{wt} \%$. In order to obtain $9 \mathrm{Cr}-\mathrm{Mo}-\mathrm{V}-\mathrm{Nb}$ ferritic steels with both high creep-rupture strength and superior toughness, the amount of delta ferrite was controlled below $25 \%$, and the optimum tempering condition and mechanical properties after simulated welding have been investigated. The influence of molybdenum content on creep-rupture strength and Charpy absorbed energy was investigated with respect to the ratio of delta ferrite to tempered martensite, the precipitates, and the microstructures.

Charpy absorbed energy of the $0.05 \mathrm{C}-9 \mathrm{Cr}-1 \mathrm{Mo}-0.15 \mathrm{~V}-0.05 \mathrm{Nb}$ steel tempered at $800^{\circ} \mathrm{C}$ and then heated at $600 \sim 650^{\circ} \mathrm{C}$ for $10^{4} \mathrm{~h}$ was as high as $20 \sim 30 \mathrm{kgf}-\mathrm{m}$. By contrast, Charpy absorbed energy of $0.05 \mathrm{C}-9 \mathrm{Cr}-2 \mathrm{Mo}-0.15 \mathrm{~V}-0.05 \mathrm{Nb}$ steel was reduced to about $4 \mathrm{kgf}-\mathrm{m}$ after heating at $600 \sim 650^{\circ} \mathrm{C}$ for $10^{4} \mathrm{~h}$. It is considered that the steel of 1 Mo shows superior toughness because of its low carbon content and a single phase of martensite. It was concluded that combination of superior creep-rupture strength and toughness can be obtained by optimum heat treatment for the $9 \mathrm{Cr}-1 \mathrm{Mo}-\mathrm{V}-\mathrm{Nb}$ steel containing $0.05 \mathrm{wt} \% \mathrm{C}$.

Key words: high chromium ferritic steels; ferritic steels; heat resisting steels; dual phase steels; creep-rupture properties ; toughness ; heat treatment ; molybdenum ; microstructures ; precipitates.
\end{abstract}

\section{1. 緒 言}

高速増殖炉における燃料被覆管として, 改良 316 オー ステナイト鋼が広く利用されている．しかしオーステナ イト鋼は応力腐食割れや，中性子照射による耐スエリン グ性など克服しなければならない難問がのこされてい る1). それに対してフェライト系鋼は耐スエリング2),

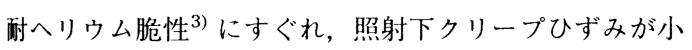
さいことからも高速増殖炉の燃料被覆管, ラッパー管用 鋼あるいは核融合第一壁候補材料としての関心も高まつ ている.

反面，フェライト系鋼はオーステナイト鋼に比べて高 温強度や使用中の靱性劣化（延性一脆性遷移温度の上昇） などの点で劣つており, 䋰念がもたれている.そこでオー
ステナイト鋼と同じ程度の高温強度を有し，鞁性にすぐ れたフェライト系鋼が要求されている。ボイラ一用鋼は ロー夕材などと異なり，すぐれた溶接性，製管性などが

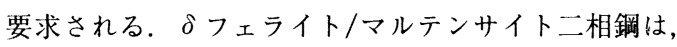
これらの久点を改善するために登場した新顔である。 $\delta$ フェライトの存在は溶接熱影響部の硬化性を抑え, $A_{1}$ 点変態点を高めることができるなどの理由から積極的に

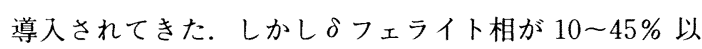
上を占めると，とくに靶性を著しく低下させるとの指摘 が多くある4)-6).

$12 \mathrm{Cr}$ 系鋼の周辺の研究はこれまで数多く手懸けられ てきたが，9〜10 Cr 系鋼については系統的，ならびに 基礎的知見を得るための研究はそれほど多くなかつ

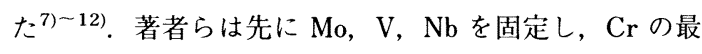

昭和 57 年 9 月本会講演大会にて発表 昭和 62 年 9 月 14 日受付 (Received Sep. 14, 1987)

* 東京大学工学部 工博 (Faculty of Engineering, The University of Tokyo, 7-3-1 Hongo Bunkyo-ku, Tokyo 113)

*2 東京大学工学部 (現: 東京大学名誉教授) 工博 (Faculty of Engineering, Now Professor Emeritus, The University of Tokyo)

*3 東京大学大学院 (現: 新日本製鉄(株)) (Graduate School, The University of Tokyo, Now Nippon Steel Corp.) 
適量を調べた結果，9〜10 Cr 付近でクリープ破断強度 が最高になることを報告した ${ }^{13)}$.また前報においては $0.05 \mathrm{C}-10 \mathrm{Cr}-\mathrm{Mo}-\mathrm{V}-\mathrm{Nb}$ 鋼（以下 $10 \mathrm{Cr}$ 系鋼と略記）の Mo 量を $0 \sim 3 \%$ （ $\delta$ フェライト量は 0 65\%）の範用で

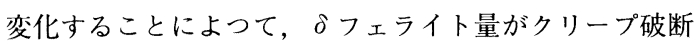
強度および靱性におよぼす影響を明らかにした ${ }^{14)}$.

本研究ではクリープ破断強度を低下させずに，耐衝撃 特性を大幅に改善するために，フェライト形成元素であ る Mo 量を 1 ～2\%の範囲で変化させることによつて, $\delta$ フェライト相を 0 〜 $25 \%$ の範囲に抑えた $9 \mathrm{Cr}$ Mo-0.15 V-0.05Nb 鋼において実験を行い, クリープ破 断強度因子，および加熱脆化因子を明らかにすることを 目的とした。

\section{2. 実 験 方 法}

\section{$2 \cdot 1$ 供試鋼および熱処理条件}

供試鋼の化学成分を Table 1 に示す. $9 \mathrm{Cr}-\mathrm{Mo}^{-}$ $0.15 \mathrm{~V}-0.05 \mathrm{Nb}$ を基本組成とする $9 \mathrm{Cr}$ 系フェライト鋼 (以下 $9 \mathrm{M}$ 系鋼と略記) において，Mo 量を 1 2 wt \% の範囲で変化させた。既に報告した $10 \mathrm{Cr}-\mathrm{Mo}$ $0.10 \mathrm{~V}-0.05 \mathrm{Nb}$ 鋼と比べて ${ }^{14)}$ ，フェライト形成元素であ る $\mathrm{Cr}$ を約 $1 \mathrm{wt} \%$, Si を $0.3 \mathrm{wt} \%$ 低下させ， $\delta$ フ イト相（以下フェライト相と略記）の生成を抑えた。な お, Vはクリープ破断強度向上のため約 $0.05 \mathrm{wt} \%$ 増量 した，供試鋼は高周波電気炉を用いて，100 kg 大気溶 解し, 鍛造により $13 \mathrm{~mm}$ の角棒にした。

クリープ破断試験片には $1050^{\circ} \mathrm{C}, 1 / 2 \mathrm{~h}$ 空冷, $700^{\circ} \mathrm{C}$, $1 \mathrm{~h}$ 空冷 (以下 $700^{\circ} \mathrm{C}$ 焼もどしと略記) および $800^{\circ} \mathrm{C}$, $1 \mathrm{~h}$ 空冷 (以下 $800^{\circ} \mathrm{C}$ 焼もどしと略記) の熱処理を施し た. シャルピー衝撃試験は $800^{\circ} \mathrm{C}$ 焼もどし後, 550 一 $650^{\circ} \mathrm{C}, 10 \sim 10^{4} \mathrm{~h}$ の加熱を施したものについて行つた.

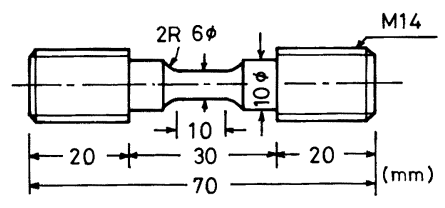

Fig. 1. Profile of the specimens after simulated welding.

\section{$2 \cdot 2$ 機械的性質}

クリープ破断試験は $550,600,650,700^{\circ} \mathrm{C}$ で行つた. 平滑材のクリープ破断試験片は直径 $6 \mathrm{~mm}$, 標点間距離 $30 \mathrm{~mm}$ を使用し，クリープ破断試験はレバー式シング ル型試験機およびバネ式マルチプル型試験機を用いた。 シャルピー衝撃試験片は所定の温度, 時間で加熱後,

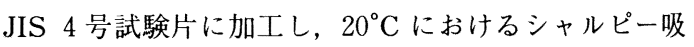
収エネルギーおよび延性一脆性遷移温度（以下 DBTT と略記）を求めた。

HAZ（溶接熱影響部）の機械的性質は溶接熱サイク ル再現装置を用いて，HAZ に相当するシミュレーショ ン処理（室温から $1350^{\circ} \mathrm{C}$ までの加熱は約 $10 \mathrm{~s}, 800^{\circ} \mathrm{C}$ から $500^{\circ} \mathrm{C}$ までの冷却時間は約 $20 \mathrm{~s}$, 以下 $\mathrm{HAZ}$ 処理と 略記）を施した後, クリープ破断強度とシャルピー吸収 エネルギーを求めた. HAZ 処理材のクリープ破断試験 片の寸法, 形状を Fig. 1 に示す. 応力除去焼なまし (PWHT) は $800^{\circ} \mathrm{C}, 1 \mathrm{~h}$ 空冷を施した.

\section{$2 \cdot 3$ 析出相の同定と組織観察}

析出相は所定の試験片を $3 \%$ 塩酸メ夕ノール電解液 中 (電流密度 : 約 $30 \mathrm{~mA} / \mathrm{cm}^{2}$ ) で 6 〜 $\mathrm{h}$ 電解分離後, 抽出残椬を採取し, $\mathrm{X}$ 線ディフラクトメーターを用いて 同定した。また主炭化物である $\mathrm{M}_{23} \mathrm{C}_{6}$ のピークにかく れた $\mathrm{M}_{23} \mathrm{C}_{6}$ 以外の析出相の挙動を調べるため, $\mathrm{M}_{23} \mathrm{C}_{6}$ を分解する $\mathrm{HCl}$ 処理を行つた.この処理は $90^{\circ} \mathrm{C} の$ $\mathrm{HCl}$ 中で抽出残椬を処理することによつて, $\mathrm{M}_{23} \mathrm{C}_{6}$ の 影響が除去できる. 微視組織は $150 \sim 200 \mathrm{kV}$ 透過電顕 を用いて観察した。

\section{3. 実 験 結 果}

\section{$3 \cdot 1$ マクロ組織とクリープ破断特性}

$9 \mathrm{M}$ 系鋼のフェライト量を Table 1 の右端, 光顕組織 を Photo. 1 に示す. 9M1 はマルテンサイト単相組織, 9M2, 9M3 はフェライト/マルテンサイトの二相組織で あり, $9 \mathrm{M} 2$ は $2 \%, 9 \mathrm{M} 3$ は $25 \%$ のフェライト量を有し ている.

クリープ破断試験の結果を Fig. 2 および Fig. 3 に示 す. Fig. 2 は $700^{\circ} \mathrm{C}$ 焼もどし, Fig. 3 は $800^{\circ} \mathrm{C}$ 焼もど しの応力-破断時間線図である. $700^{\circ} \mathrm{C}$ 焼もどしにおい ては, 短・長時間で $9 \mathrm{M} 2$ がもつとも強く, $9 \mathrm{M} 3$ がもつ とも弱い. 全般的に $700^{\circ} \mathrm{C}$ 焼もどし材のクリープ破断

Table 1. Chemical composition (wt \%) and amount of delta ferrite (\%) of steels used.

\begin{tabular}{|c|c|c|c|c|c|c|c|c|c|c|c|}
\hline Steels & $\mathrm{C}$ & $\mathrm{Si}$ & $\mathrm{Mn}$ & $\mathrm{P}$ & $\mathrm{S}$ & $\mathrm{Cr}$ & Mo & $\mathrm{V}$ & $\mathrm{Nb}$ & $\mathrm{N}$ & $\delta$-ferrite \\
\hline $\begin{array}{l}9 \mathrm{M} 1 \\
9 \mathrm{M} 2 \\
9 \mathrm{M} 3\end{array}$ & $\begin{array}{l}0.054 \\
0.065 \\
0.050\end{array}$ & $\begin{array}{l}0.17 \\
0.16 \\
0.21\end{array}$ & $\begin{array}{l}0.63 \\
0.55 \\
0.64\end{array}$ & $\begin{array}{l}0.010 \\
0.008 \\
0.011\end{array}$ & $\begin{array}{l}0.005 \\
0.006 \\
0.007\end{array}$ & $\begin{array}{l}9.17 \\
9.06 \\
9.18\end{array}$ & $\begin{array}{l}0.96 \\
1.28 \\
1.95\end{array}$ & $\begin{array}{l}0.15 \\
0.15 \\
0.15\end{array}$ & $\begin{array}{l}0.05 \\
0.04 \\
0.05\end{array}$ & $\begin{array}{l}0.028 \\
0.030 \\
0.030\end{array}$ & $\begin{array}{r}0 \\
2 \\
25\end{array}$ \\
\hline
\end{tabular}



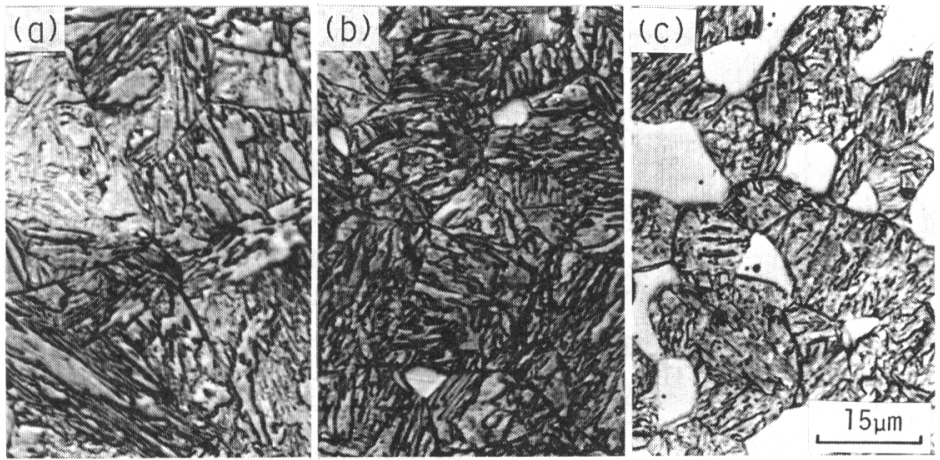

$\begin{array}{lll}\text { (a) } 9 \mathrm{M} 1 & \text { (b) } 9 \mathrm{M} 2 & \text { (c) } 9 \mathrm{M} 3\end{array}$

Photo. 1. Optical microstructures of $9 \mathrm{M}$-series steels normalized at $1050^{\circ} \mathrm{C}$.

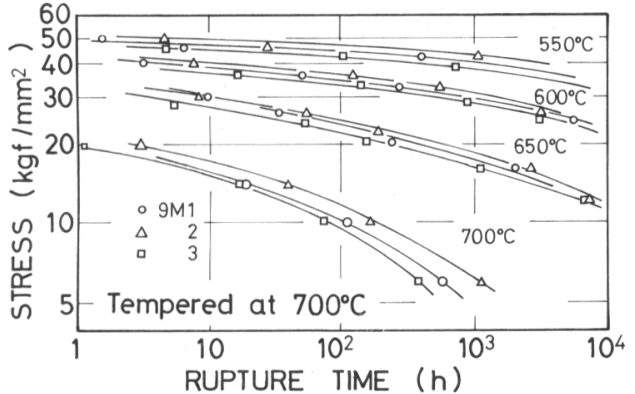

Fig. 2. Effect of molybdenum content on creeprupture strength of $9 \mathrm{M}^{-}$series steels tempered at $700^{\circ} \mathrm{C}$.

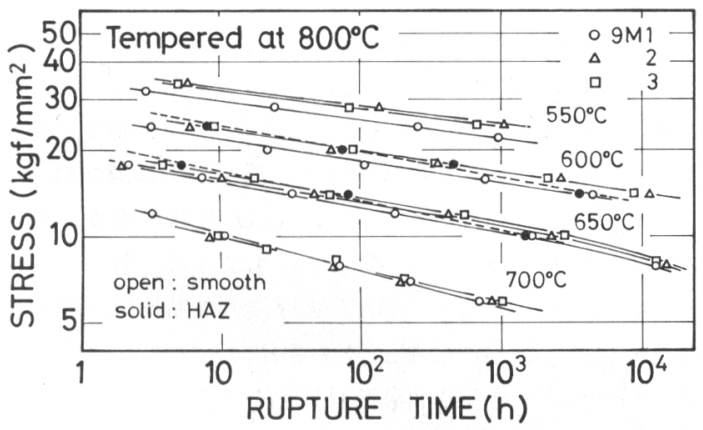

Fig. 3. Effect of molybdenum content on creeprupture strength of $9 \mathrm{M}$-series steels tempered at $800^{\circ} \mathrm{C}$.

強度の順位は試験温度にあまり影響されず，短時間およ び長時間でも $9 \mathrm{M} 2>9 \mathrm{M} 1 \geqq 9 \mathrm{M} 3$ の強度順位であり，大 きな変化はみられない. 他方, $9 \mathrm{M} 3$ の $600 \sim 650^{\circ} \mathrm{C}$, $10^{2} \mathrm{~h}$ 強度は，9M2 に比べて約 $90 \%$ （応力差で最大約 5 $\mathrm{kgf} / \mathrm{mm}^{2}$ ) であるのに対し, 目視マニュアル法と LARSON-MiLLER（ $C=35 ）$ を併用して求めた長時間外挿值 $10^{4} \mathrm{~h}$ は約 93〜 95\%（応力で $0.8 \sim 0.5 \mathrm{kgf} / \mathrm{mm}^{2}$ ) に縮ま

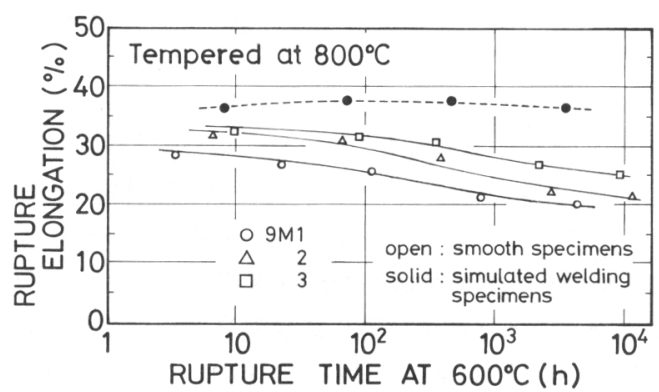

Fig. 4. Effect of molybdenum on creep-rupture elongation of $9 \mathrm{M}-$ series steels at $600^{\circ} \mathrm{C}$.

る. $9 \mathrm{M} 2$ のクリープ破断強度が高い理由は, $\mathrm{C}$ 量が他 鋼 $(0.05 \mathrm{wt} \% \mathrm{C})$ に比べてわずかに高い $(0.065 \mathrm{wt} \% \mathrm{C})$ ためと考えられる。

Fig. 3 は $800^{\circ} \mathrm{C}$ 焼もどしのクリープ破断強度を示す. Fig. 2 に示した $700^{\circ} \mathrm{C}$ 焼もどしとは多少異なつた挙動 を示し, $550 \sim 650^{\circ} \mathrm{C}$ では $9 \mathrm{M} 1$ と $9 \mathrm{M} 3$ のクリープ破断 強度は逆転し, $9 \mathrm{M} 2 \geqq 9 \mathrm{M} 3>9 \mathrm{M} 1$ の強度順位になる。 $650 \sim 700^{\circ} \mathrm{C}$ では 3 鋼種間の強度差は非常に小さい. $10^{4}$ $\mathrm{h}$ の長時間では $\mathrm{C}$ 量の多い $9 \mathrm{M} 2$ を考慮しなければ, Mo 添加の多い $9 \mathrm{M} 3$ がわずかにすぐれたクリープ破断強度 を示す。

$800^{\circ} \mathrm{C}$ 焼もどし, $600^{\circ} \mathrm{C}$ におけるクリープ破断時間破断伸びの関係を Fig. 4 に示す. 破断伸びは短時間破 断材では $25 \%$ 以上，長時間破断材でも $20 \%$ 以上ある. 一方, 図示していないが $700^{\circ} \mathrm{C}$ 焼もどしの短時間側で は 20〜15\%，長時間では破断伸びが 15〜10\%に減少す る傾向を示した。

\section{$3 \cdot 2$ 靭性（シャルピー衝撃特性）}

$20^{\circ} \mathrm{C}$ におけるシャルピー吸収エネルギー（以下吸収 エネルギーと略記）の変化を Fig. 5 に示す. Fig. 5 (a) は $1050^{\circ} \mathrm{C}, 1 / 2 \mathrm{~h}$ 焼ならし後, それぞれ $700,750,800^{\circ} \mathrm{C}$, 


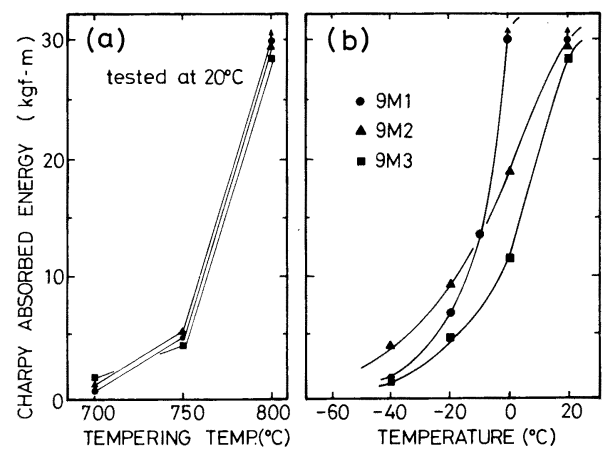

Fig. 5. Effects of tempering temperature on Charpy absorbed energy at $20^{\circ} \mathrm{C}$ (a) and ductilitybrittlement transition behavior of $9 \mathrm{M}$-series steels tempered at $800^{\circ} \mathrm{C}$.

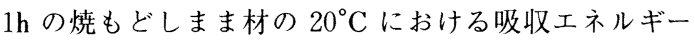
を示す。この結果, 吸収エネルギーの改善に効果的な焼 もどし温度は $800^{\circ} \mathrm{C}$ であつた. Fig. 5 （b）は $800^{\circ} \mathrm{C}$ 焼 もどしを施した $9 \mathrm{M}$ 系鋼の DBTT 特性である。上部棚 エネルギーの低下抢よび遷移温度の高温側への移行は フェライト量 (Mo 量) に依存して㧍り, マルテンサイ 卜単相の $9 \mathrm{M} 1$ の遷移温度が $-10^{\circ} \mathrm{C}$ 付近であるのに対し て，フェライト相を含有する $9 \mathrm{M} 2$ の遷移温度は $-5^{\circ} \mathrm{C}$ 付近，9M3 は $0{ }^{\circ} \mathrm{C}$ 付近である.

$800^{\circ} \mathrm{C}$ 焼もどしを施した後, $550^{\circ} \mathrm{C}$ ならびに $650^{\circ} \mathrm{C}$ で 10 1 $10^{4} \mathrm{~h}$ まで加熱を行い, $20^{\circ} \mathrm{C}$ においてシャルピー 衛撃試験を行つた結果を Fig. 6 に示す. $550^{\circ} \mathrm{C}$ では, $9 \mathrm{M} 1$ が $300 \mathrm{~h}$ までの加熱で $30 \mathrm{kgf}-\mathrm{m}$ 以上の吸収エネル ギーを有し, $10^{3} \mathrm{~h}$ 加熱で約 $20 \mathrm{kgf}-\mathrm{m}$ に低下するが, $10^{4} \mathrm{~h}$ 加熱でも $10 \mathrm{kgf}-\mathrm{m}$ 程度のすぐれた吸収エネル ギーを有する．9M 2 と $9 \mathrm{M} 3$ は似た吸収エネルギー值を 示し， $10 \mathrm{~h}$ 加熱までは $30 \mathrm{kgf}-\mathrm{m}$ 以上の吸収エネルギー を有するが，その後は緩慢に低下し， $10^{4} \mathrm{~h}$ 加熱では約 4 kgf-m に低下する.

$650^{\circ} \mathrm{C}$ では, $9 \mathrm{M} 1$ が $10^{4} \mathrm{~h}$ 加熱でも $30 \mathrm{kgf}-\mathrm{m}$ 以上の すぐれた吸収エネルギーを有する．9M 2 は $10^{2} \mathrm{~h}$ 加熱 で約 $30 \mathrm{kgf}-\mathrm{m}$ を有するが, $10^{4} \mathrm{~h}$ 加熱後では $4 \mathrm{kgf}-\mathrm{m}$ に低下する. $9 \mathrm{M} 3$ は $10 \mathrm{~h}$ 加熱で $10 \mathrm{kgf}-\mathrm{m}$ に低下し， $10^{4} \mathrm{~h}$ 加熱では $4 \mathrm{kgf}-\mathrm{m}$ に低下するが， $4 \mathrm{kgf}-\mathrm{m}$ 以下に は低下しない。このように $1 \mathrm{wt} \%$ Mo 添加の $9 \mathrm{M} 1$ が $550^{\circ} \mathrm{C}-10^{4} \mathrm{~h}, 650^{\circ} \mathrm{C}-10^{4} \mathrm{~h}$ 加熱において, すぐれた吸収 エネルギーを示した.

\section{$3 \cdot 3$ HAZ 処理後の機械的性質}

$800^{\circ} \mathrm{C}$ の焼もどしを施した $9 \mathrm{M} 1$ の $600 \sim 650^{\circ} \mathrm{C}, 10^{4}$ h クリープ破断強度は, $700^{\circ} \mathrm{C}$ 焼もどしょりも約 $65 \%$

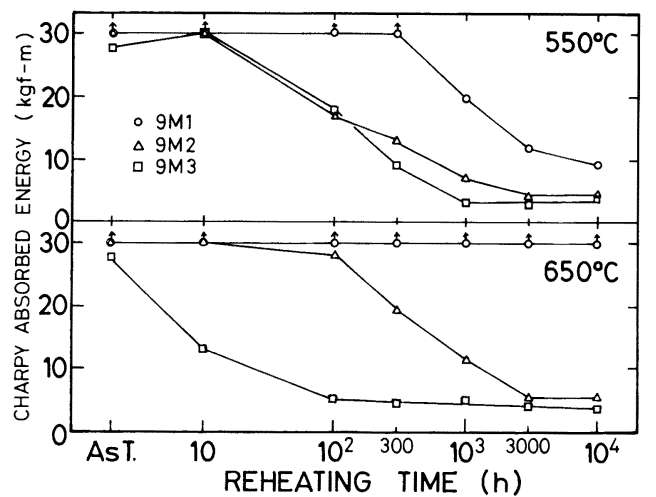

Fig. 6. Effect of molybdenum on Charpy absorbed energy of $9 \mathrm{M}^{-}$-series steels tested at $20^{\circ} \mathrm{C}$ after each heating time.

Table 2. Charpy absorbed energy (kgf-m) of $9 \mathrm{M} 1$ at $20^{\circ} \mathrm{C}$ after simulated welding.

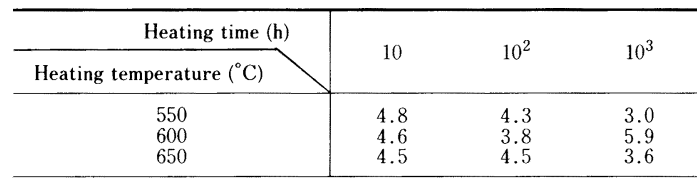

After HAZ treatment ; 0.5 kgf-m PWHT ; 4.9 kgf-m

低下するが，吸収エネルギーに関してはすぐれた值を示 した。これらの結果から，本鋼のなかでは 9M1 がもつ とも有望な鋼であると考えられる。しかし9M1 はマル テンサイト単相であるため, 溶接後の機械的性質の劣化 に䯚念がある。このため $9 \mathrm{M} 1$ に HAZ 処理を施し，ク リープ破断強度とシャルピー衛撃特性を以下に調べた。

クリープ破断強度については，HAZ 処理しなかった ものに比較して Fig. 3 のの印で示すように, 著しい強 度低下は認められない.HAZ 処理後の破断部位は母材 側であり，破断伸びは Fig. 4 のの印に示すように $35 \%$ 以上あつた。また長時間破断材に扔いても破断伸びの著 しい低下，すなわちクリープ脆化は認められずとくに問 題はないものと考えられる.

他方, $20^{\circ} \mathrm{C}$ における吸収エネルギーの変化を Table 2 に示す. HAZ 処理直後では $0.5 \mathrm{kgf}-\mathrm{m}$ 程度に低下寸 るが, PWHT を施すと約 $5 \mathrm{kgf}-\mathrm{m}$ まで回復する.その後, $550 \sim 650^{\circ} \mathrm{C}, 10^{3} \mathrm{~h}$ 加熱した供試鋼の吸収エネルギーは, 3〜 $5 \mathrm{kgf}-\mathrm{m}$ 程度で大きな低下は認められなかつた。

\section{4. 考}

\section{察}

実験結果が示すように, 従来鋼に比べると ${ }^{13114)}$ クリー プ破断強度の向上と靸性の改善は， $800^{\circ} \mathrm{C}$ 焼もどしを施 
した 9M1 において一応果たされたものと考えられる. そこで 9M 系鋼の本質的な相違を微視組織, 析出挙動 などによつて調べた。

\section{$4 \cdot 1$ クリープ破断強度におよぼす Mo 量の影響}

$10^{2} \sim 10^{4} \mathrm{~h}$ クリープ破断強度と Mo 量の関係を Fig. 7 に示す. $700^{\circ} \mathrm{C}$ 焼もどしにおいては, $550 \sim 650^{\circ} \mathrm{C}$ の 短時間側，長時間側でともに $9 \mathrm{M} 2$ がすぐれた強度を示 した。これは前述したように，9M2 のC量が他鋼に比 べて，わずかに高いためと考えられる. $600 \sim 650^{\circ} \mathrm{C}$, $10^{4} \mathrm{~h}$ の長時間クリープ破断強度は, Mo 添加量の少な い鋼ほどクリープ破断曲線の傾きがわずかに急である. この傾向に対して， $550^{\circ} \mathrm{C}, 10^{4} \mathrm{~h}$ では $9 \mathrm{M} 1$ が $9 \mathrm{M} 3$ よ り高い強度を示している。これは $9 \mathrm{M} 1$ のマトリックス の回復が, $700^{\circ} \mathrm{C}$ 焼もどし $+550^{\circ} \mathrm{C}$ 加熱ではそれほど促

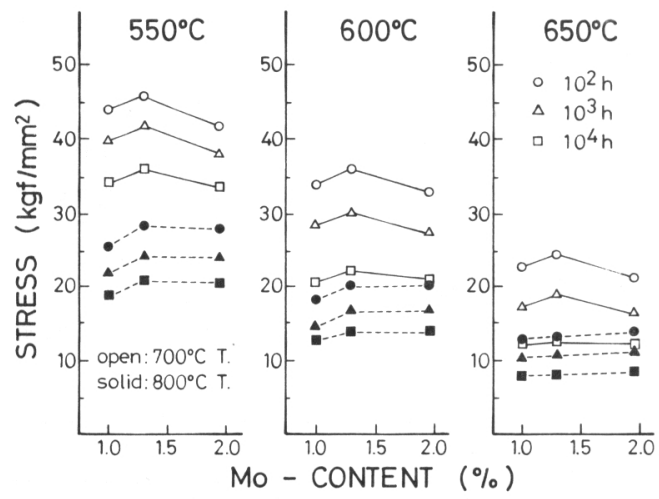

Fig. 7. Effect of molybdenum on $10^{2}-10^{4} \mathrm{~h}$ creeprupture strength of $9 \mathrm{M}$-series steels tempered at $700^{\circ} \mathrm{C}$ and $800^{\circ} \mathrm{C}$.
進されないため, マルテンサイト固有の強度が反映され た結果と考えられる.

$700^{\circ} \mathrm{C}$ 焼もどしでは，マルテンサイトを $98 \%$ 含み， $\mathrm{C}$ 量がわずかに高い $9 \mathrm{M} 2$ が有利であつた。 $800^{\circ} \mathrm{C}$ 焼も どしになるとマルテンサイトもかなり回復した初期組織 になるが， $550^{\circ} \mathrm{C}$ のクリープ破断強度は $9 \mathrm{M} 2$ がわずか に高い強度を示す。しかし $600 \sim 650^{\circ} \mathrm{C}$ クリープ破断強 度に関しては $9 \mathrm{M} 3$ が有利になる。この理由はフェライ ト/マルテンサイト二相鋼においては Mo がフェライト 相に濃縮されるため ${ }^{15)}$, フェライト・マトリックスが固 溶強化されると共に ${ }^{14)}$, フェライト相へ $\mathrm{M}_{6} \mathrm{C}$, Laves 相 $\left(\mathrm{Fe}_{2} \mathrm{Mo}\right)$ などが微細析出し ${ }^{16)}$, クリープ破断強度を 向上させるものと考えられる.

著者らは先に報告した $10 \mathrm{Cr}$ 系鋼のクリープ破断強度 に関し，Moの増量は，フェライト相の増加を誘引する 反面, Mo の固溶強化と析出強化の寄与により, 強度向 上に効果的であると結論づけた。またMoを含有しな い, あるいは Mo 添加量の少ないマルテンサイト単相 鋼（0〜0.5 wt\% Mo）は, $10^{3} \mathrm{~h}$ 程度の短時間強度や, 比較的温度の低い $550^{\circ} \mathrm{C}$ においては, 2 3 wt \% Mo 添 加鋼とほほ同じ程度のクリープ破断強度を示すが, 長時 間，あるいは $600 \sim 650^{\circ} \mathrm{C}$ になると急激に焼もどされて， 著しい強度低下を示すことを報告した ${ }^{14)}$.

本系鋼も同じような傾向を示したが, $10 \mathrm{Cr}$ 系鋼の場 合にはマルテンサイト単相を得るためには $0 \%$ Mo でな ければならなかつた。しかし, マルテンサイト単相の 9M1 には Mo が $1 \mathrm{wt} \%$ 添加されているため, 長時間側 でも大きな強度の低下が認められなかつたものと考えら れる. $9 \mathrm{M} 3$ はフェライト相を約 $25 \%$ 含有しながらも,
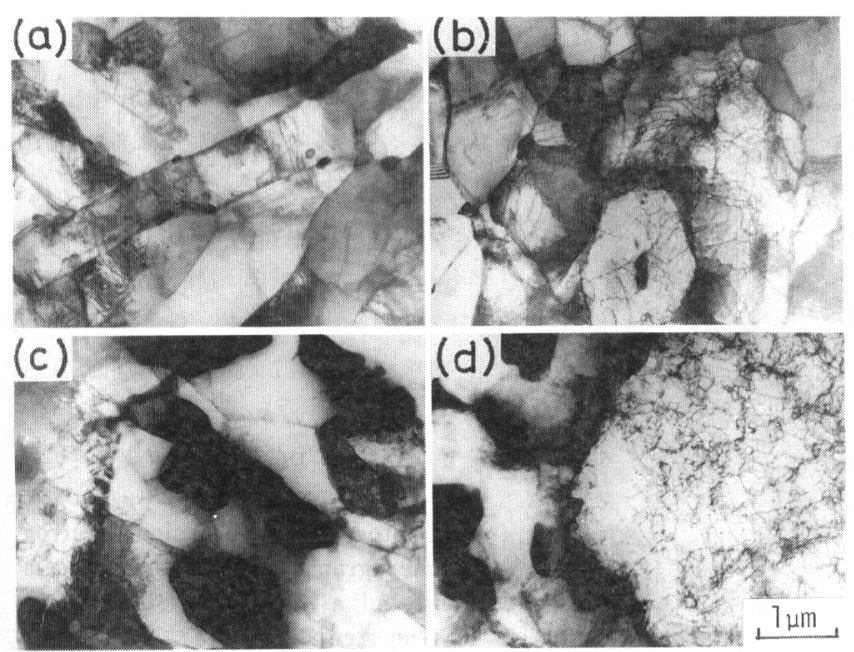

(a), (b) $9 \mathrm{M1}: 30 \mathrm{kgf}-\mathrm{m}$ (c), (d) $9 \mathrm{M} 3: 5.7 \mathrm{kgf}-\mathrm{m}$

Photo. 2. Transmission electron micrographs of $9 \mathrm{M}$-series steels heated at $650^{\circ} \mathrm{C}$ for $10^{4} \mathrm{~h}$ after tempered at $800^{\circ} \mathrm{C}$. 
Mo の固溶強化と析出強化が促進されるため，600〜 $650^{\circ} \mathrm{C}$ の長時間クリープ破断強度の向上に多少とも寄与 したと考えられるが，その効果は小さい。このように本 系鋼の場合，各鋼のフェライト量が相対的に少ないこと と，9M2 の C 量が高いことを考慮すれば，前述したよ うに長時間クリープ破断強度はそれほど著しい強度差を 有しないと考えられる.

\section{$4 \cdot 2$ 靶性と微視組織}

$650^{\circ} \mathrm{C}, 10^{4} \mathrm{~h}\left(800^{\circ} \mathrm{C}\right.$ 焼もどし) 加熱後の $9 \mathrm{M} 1$ と, 9M3 の微視組織を Photo. 2 に示す。勒性のすぐれた 9M1の $650^{\circ} \mathrm{C}$ 加熱材は Photo. 2 (a) および（b）に示 すように，析出相はマルテンサイト粒内にわずかに観察 される程度であるが，マトリックスのポリゴン化は 9M3 に比べて進んでいる.9M3 は Photo. 2 (c) およ び（d）に示すように，マルテンサイト粒内に 0.5 1 $\mu \mathrm{m}$ 程度の粗大炭化物, フェライト粒内には $15 \sim 30 \mathrm{~nm}$ 程度の微細炭化物が多数観察されたが，マトリックスの 回復は 9M1 ほど促進されていない。けれども，フェラ イト/マルテンサイト界面は Photo. 2(d)に示すように, 塊状とフィルム状の析出相が多数観察された.

$550^{\circ} \mathrm{C}, 10^{4} \mathrm{~h}\left(800^{\circ} \mathrm{C}\right.$ 焼もどし) 加熱においては, 吸 収エネルギーが大きく低下した 9M1 のマルテンサイト ・ラス境界には Photo. 3 （a）抢よび（b）に示すように, 局所的に $0.5 \mu \mathrm{m} \phi$ 程度の炭化物が旧オーステナイト粒 界に沿つて観察できる.

9M3 の $550^{\circ} \mathrm{C}$ 加熱に扮ける炭化物は Photo. 3 (c) （e）に示すように，フェライト/マルテンサイト界面に フィルム状に連続析出しているのが認められる. 走査電 顕によって破面観察を行うと，析出相が粒界などにフィ ルム状に分布したとき, 破面形態は擬へき開，あるいは
粒界破面を呈することがわかつている ${ }^{17)}$.したがつて フィルム状に析出した場合，ほとんど䩲性值は低い。こ のように吸収エネルギーの低下には析出相の形態，分布 が大きく関与していることがわかる.

$550^{\circ} \mathrm{C}$ および $650^{\circ} \mathrm{C}, 10^{4} \mathrm{~h}$ 加熱後の吸収エネルギー は，9M2 や 9M3 に比べてマルテンサイト単相の 9M1 がすぐれている．9M1 の吸収エネルギーは加熱温度に 大きく影響され， $650^{\circ} \mathrm{C}, 10^{4} \mathrm{~h}$ では $30 \mathrm{kgf}-\mathrm{m}$ 以上ある のに対して, $550^{\circ} \mathrm{C}, 10^{4} \mathrm{~h}$ では約 $10 \mathrm{kgf}-\mathrm{m}$ に低下する. $9 \mathrm{M} 1$ のすぐれた靱性は最適な Mo 量 $(1 \mathrm{wt} \%)$ と, 最 適な $\mathrm{C}$ 量 $(0.05 \mathrm{wt} \%)$ 抒よびマルテンサイト単相組織 の因子とによつて説明できる，仮に Mo 量が多すぎる とフェライト相が増し，C量が多いと析出相の凝集化

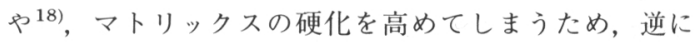
脆化を促進するものと考えられる。これは HT9 (0.2 wt $\% \mathrm{C})$ や Modified 9Cr-1Mo (0.1 wt \%C) にもみられ る挙動である ${ }^{19}$. HAZ 处理した $9 \mathrm{M} 1$ が著しい劣化を 生じなかつた理由は，マルテンサイト単相であつても最 適な $\mathrm{C}$ 量であるために, 適度なマトリックスの回復と, 析出相の微細化を促進し, 溶接後の硬化㧍上び加熱脆化 を抑制したものと考えられる。

\section{$4 \cdot 3$ 析 出 挙 動}

Table 3 は $800^{\circ} \mathrm{C}$ 焼もどし後, $650^{\circ} \mathrm{C}$ で所定の時間

Table 3. Identified precipitates in 9M-series steels heated at $650^{\circ} \mathrm{C}$ after tempering at $800^{\circ} \mathrm{C}$.

\begin{tabular}{|c|c|c|c|c|c|}
\hline Steels & As-tempered & $10 \mathrm{~h}$ & $100 \mathrm{~h}$ & $300 \mathrm{~h}$ & $1000 \mathrm{~h}$ \\
\hline $9 \mathrm{M} 1$ & $\mathrm{M}_{23} \mathrm{C}_{6}$ & $\mathrm{M}_{23} \mathrm{C}_{6}$ & $\mathrm{M}_{23} \mathrm{C}_{6}$ & $\mathrm{M}_{23} \mathrm{C}_{6}$ & $\mathrm{M}_{23} \mathrm{C}_{6}$ \\
\hline 9M3 & $\mathrm{M}_{23} \mathrm{C}_{6}$ & $\begin{array}{l}\mathrm{M}_{23} \mathrm{C}_{6} \\
\mathrm{M}_{6} \mathrm{C}(\mathbf{w})\end{array}$ & $\begin{array}{l}\mathrm{M}_{23} \mathrm{C}_{6} \\
\mathrm{Fe}_{2} \mathrm{Mo} \\
\mathrm{M}_{6} \mathrm{C}\end{array}$ & $\begin{array}{l}\mathrm{M}_{23} \mathrm{C}_{6} \\
\mathrm{Fe}_{2} \mathrm{Mo} \\
\mathrm{M}_{6} \mathrm{C}\end{array}$ & $\begin{array}{l}\mathrm{M}_{23} \mathrm{C}_{6} \\
\mathrm{Fe}_{2} \mathrm{M}_{0}\end{array}$ \\
\hline
\end{tabular}

(w); Weak

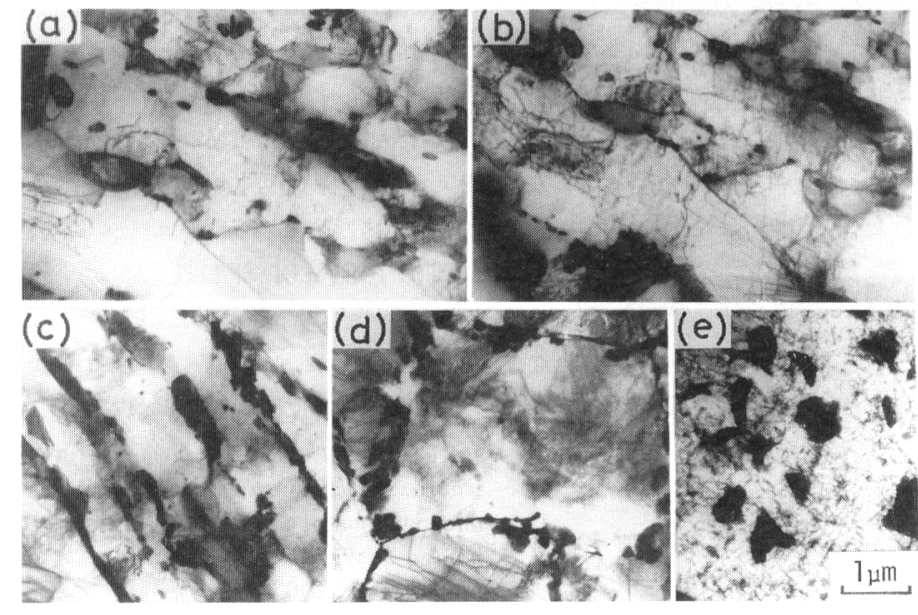

(a), (b) $9 \mathrm{M1}: 9.3 \mathrm{kgf}-\mathrm{m}$ (c) $\sim$ (e) $9 \mathrm{M} 3: 3.8 \mathrm{kgf}-\mathrm{m}$

Photo. 3. Transmission electron micrographs of 9M-series steels heated at $550^{\circ} \mathrm{C}$ for $10^{4} \mathrm{~h}$ after tempered at $800^{\circ} \mathrm{C}$. 


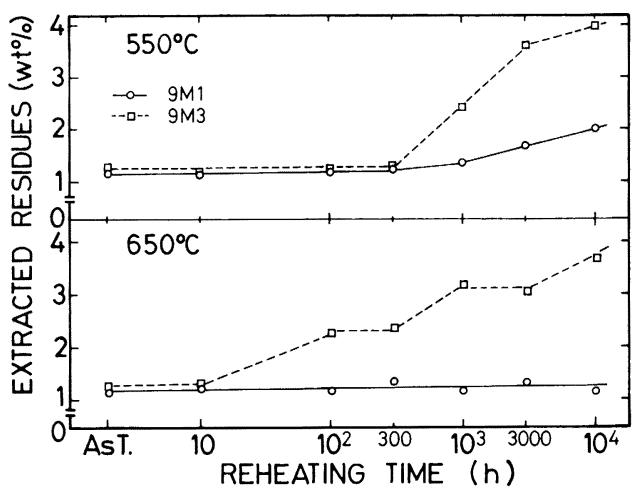

Fig. 8. Change in amount of residues extracted from steels $9 \mathrm{M} 1$ and $9 \mathrm{M} 3$ heated at $550^{\circ} \mathrm{C}$ and $650^{\circ} \mathrm{C}$ for $10^{-1} 10^{4} \mathrm{~h}$.

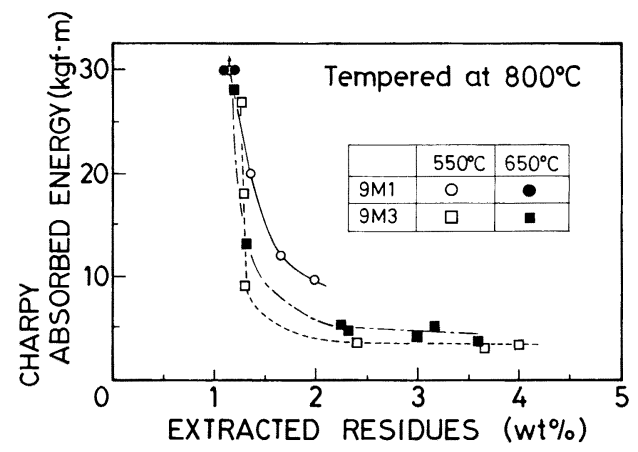

Fig. 9. Relationship between Charpy absorbed energy and extracted residues of steels $9 \mathrm{M} 1$ and $9 \mathrm{M} 3$ tempered at $800^{\circ} \mathrm{C}$.

加熱した $9 \mathrm{M} 1$ と $9 \mathrm{M} 3$ の析出相を同定した結果である. $9 \mathrm{M} 1$ の析出相は $\mathrm{M}_{23} \mathrm{C}_{6}$ が主であり, $9 \mathrm{M} 3$ は $\mathrm{M}_{23} \mathrm{C}_{6}$ 以 外に $10 \mathrm{~h}$ 後に $\mathrm{M}_{6} \mathrm{C}, 10^{2} \mathrm{~h}$ 後には $\mathrm{Fe}_{2} \mathrm{Mo}$ (Laves 相) が検出される. $\mathrm{M}_{6} \mathrm{C}$ は $10^{3} \mathrm{~h}$ 加熱で消失したと錯覚し がちであるが, $\mathrm{M}_{23} \mathrm{C}_{6}, \mathrm{Fe}_{2} \mathrm{Mo}$ などの格子定数值が $\mathrm{M}_{6} \mathrm{C}$ と重なり合うための現象であり ${ }^{15)}, \mathrm{M}_{23} \mathrm{C}_{6}$ や $\mathrm{Fe}_{2} \mathrm{Mo} に$ 比べて, $\mathrm{M}_{6} \mathrm{C}$ は少量析出であることを示唆している.

9M1 および $9 \mathrm{M} 3$ の加熱材を電解分離し, その残椬重 量 (析出相重量) を測定した結果を Fig. 8 に示す. $550^{\circ} \mathrm{C}$ 加熱では 9M1（マルテンサイト単相鋼）の残椬 重量の変化は小さいが, 9M3（フェライト/マルテンサ イト二相鋼）は $10^{3} \sim 10^{4} \mathrm{~h}$ にかけて急激に増加する. $650^{\circ} \mathrm{C}$ 加熱では $9 \mathrm{M} 1$ の残渣重量はほとんど変化が見ら れないのに対し， $9 \mathrm{M} 3$ は $10^{2} \mathrm{~h}$ 加熱以後に著しく増加 する.これらの結果を Fig. 6 の吸収エネルギーの変化 と比べると, 吸収エネルギーが低下する時点より遅れて

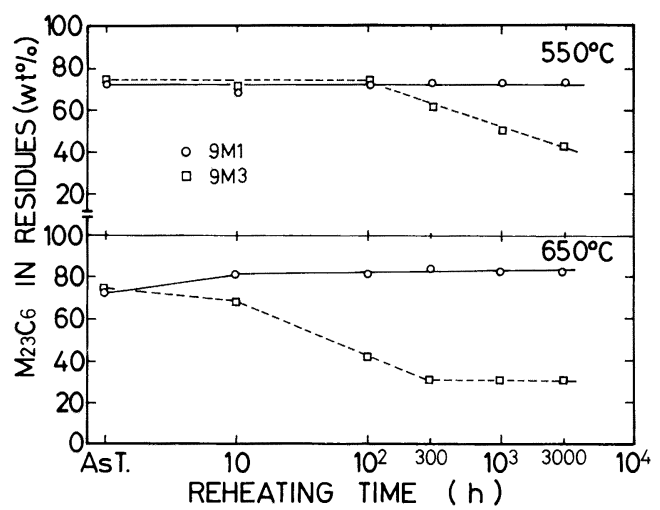

Fig. 10. The ratio of $\mathrm{M}_{23} \mathrm{C}_{6}$ in residues extracted from steels $9 \mathrm{M} 1$ and $9 \mathrm{M} 3$ heated at $550^{\circ} \mathrm{C}$ and $650^{\circ} \mathrm{C}$ for $10-10^{4} \mathrm{~h}$.

残椬重量は増加する。ただし $9 \mathrm{M} 1$ の $550^{\circ} \mathrm{C}$ 加熱におい てはほとんど一致している. $9 \mathrm{M} 3$ の $550^{\circ} \mathrm{C}$ 加熱では $10^{2} \mathrm{~h}$ で吸収エネルギーが低下しはじめるが, 残椬重量 の増加は $10^{3} \mathrm{~h}$ 後にみられる. $9 \mathrm{M} 3$ の $650^{\circ} \mathrm{C}$ 加熱は $10 \mathrm{~h}$ で吸収エネルギーが低下しはじめているが, 残椬重 量は $10^{2} \mathrm{~h}$ 後に増加する.また $9 \mathrm{M} 1$ は $650^{\circ} \mathrm{C}$ 加熱では 吸収エネルギーの低下がほとんど見られないが，このと きの残椬重量の変化は前述したように小さい.

このように $9 \mathrm{M}$ 系鋼は吸収エネルギーの低下と, 残 椬重量の増加とは密接な関係にあり, 残椬重量と吸収工 ネルギーの関係を図示すると Fig. 9 のようになる.こ の結果, 残椬重量が約 $1.5 \mathrm{wt} \%$ 以上になると吸収エネ ルギーは著しく低下する傾向を示している.

Fig. 8 で得られた $9 \mathrm{M} 1$ と $9 \mathrm{M} 3$ の残渣を, $90^{\circ} \mathrm{C} の$ $\mathrm{HCl}$ 中で処理すると $\mathrm{M}_{23} \mathrm{C}_{6}$ のみが溶解し, 残椬中に占 める $\mathrm{M}_{23} \mathrm{C}_{6}$ の割合は Fig. 10 のようになる. $550^{\circ} \mathrm{C}$ 加 熱における $\mathrm{M}_{23} \mathrm{C}_{6}$ の割合は, $9 \mathrm{M} 1$ が $3000 \mathrm{~h}$ までほほ 一定であるのに対し，9M3 はすでに $300 \mathrm{~h}$ で変化がみ られ, $\mathrm{M}_{23} \mathrm{C}_{6}$ の割合が減少する. $650^{\circ} \mathrm{C}$ 加熱材でも

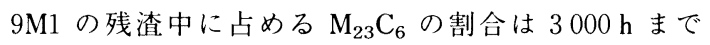
$80 \%$ 前後でほほ一定である. 他方, $9 \mathrm{M} 3$ は $10 \mathrm{~h} て ゙$ 早く も $\mathrm{M}_{23} \mathrm{C}_{6}$ の割合が減少し, $300 \mathrm{~h}$ では約 $30 \%$ まで急激

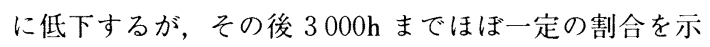
す. 残椬中に占める $\mathrm{M}_{23} \mathrm{C}_{6}$ の炭化物重量は実質的に増 減がなく, $650^{\circ} \mathrm{C}$ 加熱の場合は $\mathrm{Fe}_{2} \mathrm{Mo}$ が増加したため, $\mathrm{M}_{23} \mathrm{C}_{6}$ の比率が相対的に減少したものと考えられる. また残椬中に占める $\mathrm{M}_{23} \mathrm{C}_{6}$ の割合は Fig. 6 に示した吸 収エネルギーの変化とよく対応している.

$\mathrm{HCl}$ 処理後の残椬を $\mathrm{X}$ 線ディフラクトメーターによ つて再び同定すると Table 4 に示すように, $9 \mathrm{M} 1$ には 
Table 4. Identified precipitates in residues of $9 \mathrm{M}$-series steels after $\mathrm{HCl}$-treatment heated at $650^{\circ} \mathrm{C}$ tempered at $800^{\circ} \mathrm{C}$.

\begin{tabular}{c|cllll}
\hline Steels & As-tempered & $10 \mathrm{~h}$ & $100 \mathrm{~h}$ & $300 \mathrm{~h}$ & $1000 \mathrm{~h}$ \\
\hline \multirow{2}{*}{$9 \mathrm{M} 1$} & $\mathrm{VC}$ & $\mathrm{VC}$ & $\mathrm{VC}$ & $\mathrm{VC}$ & $\mathrm{VC}$ \\
& $\mathrm{NbC}$ & $\mathrm{NbC}$ & $\mathrm{NbC}$ & $\mathrm{NbC}$ & $\mathrm{NbC}$ \\
\hline \multirow{2}{*}{$9 \mathrm{M} 3$} & $\mathrm{VC}$ & $\mathrm{VC}$ & $\mathrm{Fe}_{2} \mathrm{Mo}$ & $\mathrm{Fe}_{2} \mathrm{Mo}$ & $\mathrm{Fe}_{2} \mathrm{Mo}$ \\
& $\mathrm{NbC}$ & $\mathrm{NbC}$ & $\mathrm{NbC}$ & $\mathrm{NbC}^{2}$ & \\
\hline
\end{tabular}

$\mathrm{VC}$ および $\mathrm{NbC}$ が検出され，9M には $10^{2} \mathrm{~h}$ 後,

$\mathrm{Fe}_{2} \mathrm{Mo}$ がそれらに加わる.この炭化物が $\mathrm{HCl}$ 処理前に 検出されなかつたのは, $\mathrm{M}_{23} \mathrm{C}_{6}$ のピークにかくれてい たためであり，Table 3 で得られなかつた VC, NbC の炭化物はクリープ破断強度の向上に実際には寄与して いるものと考えられる。著者らは EDSを用いて $10 \mathrm{Cr}-2 \mathrm{Mo}-\mathrm{V}-\mathrm{Nb}$ 鋼で形成された岑化物の合金組成を分 析した結果， $\mathrm{V}$ は $\mathrm{M}_{23} \mathrm{C}_{6}$ の $\mathrm{M}$ 中に固溶して炭化物の凝 集・粗大化を遅らせることを報告したが15)，本系鋼から は単独の $\mathrm{VC}$ が検出された。一方， $10 \mathrm{Cr}$ 系銅では $\mathrm{NbC}$ は短時間側で単独に検出されている。したがつてVは炭 化物中に固溶して粗大化を抑制する効果と, VCとして 析出強化する効果が相乗するものと考えられる.

以上，溶接性ならびに製管性，さらにクリープ破断強 度，靶性などを考虑した場合，9Cr 系鋼の Mo の最適 量は $1.2 \sim 1.5 \mathrm{wt} \%$ 前後であるが, 靫性を重点に考える ときは $1.0 \mathrm{wt} \%$ が最適量であると指摘できる.

\section{5. 結}

$\overline{\overline{\bar{D}}}$

フェライト鋼のクリープ破断強度と䩲性を大幅に问上 させ，ならびに $9 \mathrm{Cr}$ 系鋼における強度および脆化因子 を調べるために，0.05C-9Cr-Mo-0.15 V-0.05 Nb 鍋の Mo量を変化し, 得られた結果をまとめると次のように なる。

$1 ）$ クリープ破断強度におよぼす Mo 量の影響は, $800^{\circ} \mathrm{C}$ 焼もどしを施した $0.05 \mathrm{C}-9 \mathrm{Cr}-\mathrm{Mo}-0.15 \mathrm{~V}$ $0.05 \mathrm{Nb}$ 系鋼の場合には著しい破断強度の差は認められ ない.

2 ) $0.05 \mathrm{C}-9 \mathrm{Cr}-1 \mathrm{Mo}-0.15 \mathrm{~V}-0.05 \mathrm{Nb}$ 鋼の吸収エネル ギーは $600 \sim 650^{\circ} \mathrm{C}, 10^{4} \mathrm{~h}$ 加熱後でも $20 \sim 30 \mathrm{kgf}-\mathrm{m}$ あ り，良好な靱性が得られた。この高い靱性は析出相の凝 集化を抑制した最適な合金設計と，焼もどしマルテンサ イト単相組織によると考えられる.

3) シャルピー衝撃特性におよぼすMo量の影響は大 きく, Mo の増量添加はフェライト相を増し, 吸収エネ ルギーの低下を促進する.
4 ）クリープ破断強度およびシャルピー衝撃特性を考 慮すると，本系鋼に対しては，1.2 1.5 wt\% Mo が最 適量であるが，鞉性を重視するときは $1.0 \mathrm{wt} \% \mathrm{Mo}$ 最 適量である。

5 ) シャルピー吸収エネルギーは, Mo の増量添加に よつて $\mathrm{M}_{6} \mathrm{C}, \mathrm{Fe}_{2} \mathrm{Mo}$ などの析出相が増量（残椬重量で $1.5 \mathrm{wt} \%$ 以上）すると，著しく低下する。

6 ) Vは炭化物中に固溶して粗大化を抑制する効果と, $\mathrm{VC}$ として析出強化する効果が相乗するため, クリープ 破断強度を向上させるものと考えられる.

本研究の一部は文部省科学研究費一般研究（昭和 56 年度）および試験研究（昭和 57 年度）によつたことを 付記する。

\section{文献}

1) J. L. Scott, E. E. Bloom, M. L. Groddbeck, P. J. Maziasz, $F$. $W$. Wiffen, $R . E$. Gold, $J . J$. Holmes, T. $C$. Reuther and $S$. N. Rosenwasser: Proc. Fourth Topical Meeting on the Technol. Controlled Nuclear/Fusion, Pennsylvania（1980 年 10 月）

2 ) E. A. LitTlE: J. Nucl. Mater., 87 (1979), p. 11

3 ) T. M. Williams and D. R. Arkel.l. J. Nucl. Mater., 88 (1980), p. 111

4 ) H. W. HAYden and S. FlorRen: Metall. Trans., 1 (1970), p. 1955

5 ) 太田定雄, 藤原優行, 内田博幸: 学振 123 委研究報告, 26 (1985), p. 41

6 ）朝倉健太郎，藤田利夫，三宅英徳：鉄と鋼，69（1983）, p. 2037

7 ) J. GLEN: Iron Steel Inst., 158 (1948), p. 37

8 ) R. T. KING and L. EgNELL; Ferritic steels for fast reactor steam generators, BNES, London (1978), p. 74

9 ) P. J. Grobner and D. L. SPonseller: Metall. Trans. A, 11 (1980), p. 709

10) P. Billard, J. R. Donati, D. Guttmann, S. Licheron and $J$. C. Van DuYson: Proc. Topical Conference on Ferritic Alloys for use in Nuclear Energy Technologies, Snowbird (1983), p. 425

11) W. R. CORWIN, J. M. VITEK and R. L. KLUEH; J. Nucl. Mater., 149 (1987), p. 312

12）行俊照夫, 吉川州彦，時政勝行，志田善明，稲葉洋次: 鉄と鋼, 65 (1979), p. 876

13）朝倉健太郎，藤田利夫，山下幸介：鉄と鋼，66（1980）, p. 1375

14）朝倉健太郎，藤田利夫，乙黒靖男: 鉄と鋼，73（1987）, p. 1762

15）朝倉健太郎, 藤田利夫: 学振 123 委研究報告, 21 (1980) 2, p. 27

16) $T$. Fujita, $K$. Asakura, $T$. Sawada, $T$. Takamatsu and $Y$. OTOGURO: Metall. Trans. A, 12 (1981), p. 1071

17) 朝倉健太郎, 藤田利夫: 学振 123 委研究報告, 26 (1985), p. 501

18) D. S. GELLEs: Ferritic Steels for High-Temperature Applications, ASM, Pennsylvania (1981) Oct., p. 197 